\title{
NATO War Medicine Doctrine Revisited in Bosnia and Herzegovina
}

\author{
$\checkmark$ Šarić \\ $\checkmark$ Atias-Nikolov \\ T Kovač \\ E Franković \\ V Mršić \\ J Lukač
}

Medical Center Livno, Bosnia and Herzegovina

SUMMARY: NATO war medical doctrine was applied in the war in Croatia, Bosnia and Herzegovina. However, due to rather specific martial and organizational circumstances, the doctrine had to be modified. sometimes substantially. A medical team from the war hospital in Livno, Bosnia and Herzegovina decribes their work with respect to the four-echelon NATO doctrine. The team covered a relatively large and active battlefield, and treated 597 patients with 314 major surgical interventions. Due to the lack of surgeons and medical personnel in general, the second echelon concentrated on fast transportation, and the third echelon fulfilled the function of the fourth echelon, completing the surgical treatment except for 12 patients with head and spine injuries.

The way, time and circumstances in which Bosnia and Herzegovina was recognized as an independent and sovereign state on the one hand, and a highly delicate political situation and ethnic relations on the other, make the war in Bosnia and Herzegovina a highly specific one. In the spring of 1992 Croats and Muslims had neither regular army forces nor organized logistics and rear echelon, thus they were vulnerable to the strong and wellorganized Yugoslav Federal Army (YFA) and many Serbian paramilitary formations. The parliament, government and presidium of the newly formed state of Bosnia and Herzegovina, consisting of Croats, Serbs and Muslims were dissolved and the legislative, executive and judiciary power ceased to exist. The national economy and production were destroyed within a short time. After a few months, about $50 \%$ of the territory was controlled by the YFA and Serbian paramilitary forces.

\footnotetext{
Public Health Service in Bosnia and Herzegovina during the First Year of the War

General disintegration of Bosnia and Herzegovina also affected the public health service. In the part controlled by the Croats and Muslims each medical facility operated independently and managed to remain in function only owing to the enthusiastic efforts of its medical personnel and abundant donations given by numerous individuals and organizations from all parts of the world. Despite such chaos, the public health service system had to be organized in order to provide health care to the population, but also to treat growing numbers of war casualties, both soldiers and civilians. In addition to the lack of organized regular army forces, Croats and Muslims did not have organized military medical care. Therefore, the already existing civilian medical
}

institutions took over the organization of all types of military medical services, including the system of the emergency war surgical care.

Organization and Operation of War Surgical Care in Bosnia and Herzegovina

The NATO Handbook of Emergency War Surgery (1) served as a basis for the formation and further development of war surgical care system in Bosnia ando Herzegovina. However, specific circumstances dictated certain modifications of the NATO schemes. Of coursese departures from the basic principles of surgical; resuscitation and anaesthetic management could not be made, but some changes in the staged management of the wounded were necessary. Bearing in mind the autonomous operation of each medical institution, the evacuation of the wounded was organised and performed to the best of the abilities of each medical institution and depending upon the war circumstances. It has to be pointed out that within the borders of Bosnia and Herzegovina there was no rear, and consequently no fourth echelon. Owing to the fact that Croatia has and is still, accepting all the wounded from Bosnia and Herzegovina, it has been possible to have the war casualties treated securely in rear medical facilities in Croatia.

We want to present our modification of the third echelon, using the example of the Sturba war hospital near the town of Livno in the southwest part of Bosnia and Herzegovina, fully controlled by Croats and Muslims.

Phased Approach to Management of War Casualties in the Livno Battlefield

The NATO medical doctrine of echelonment recommends that the surgical care at the level of the third echelon should not comprise complete surgical 
management but only initial surgical effort to save life and $\operatorname{limb}$, prevent infection and render the casualty transportable to a rear medical facility (1). We think that this recommendation has been based upon the assumption that in the long and change-prone evacuation chain casualties are cared for by an undefined number of surgeons of various nationalities.

Our opinion is that such a concept of treatment at the level of the third echelon has been designed for powerful and well-organized multinational armies whose possible war operations would be waged in large areas, perhaps in foreign territory, supported with excellent logistics and always secure rear in the home countries.

A well-equipped war hospital was located at Sturba, 5 $\mathrm{km}$ away from the town of Livno (2). When planning the organization of war surgical service system we decided that the evacuation chain of the casualties from the Livno battlefield should end at this hospital, which was at the level of the third echelon of medical care. Contrary to the NATO war doctrine, complete surgical care was given to casualties at this hospital in terms of definitive treatment of acute trauma. In case of severely wounded persons, especially those with life-threatening injuries, surgery, resuscitation and anaesthesia were done simultaneously because we adhered to the principle that surgical intervention was an integral part of resuscitation and that resuscitation without simultaneous complete surgical care would prove unsuccessful. Intensive care was continued during the postoperative course until stabilization of vital functions and the general condition, as well as elimination of early complications. After this, patients were transported to a fourth echelon medical facility, i.e. various hospitals in Croatia, mostly in Split and Zagreb (2).

Being close to the first front lines and having wellorganized road evacuation, casualties were transported to Sturba shortly after wounding, and those most seriously wounded were operated on within $1-1.5$ hours post injury. It was more than once that we were made aware of the importance of time in salvation of life and limb, as well as prevention of infection. The same conviction was shared by surgical and anaesthesiological teams assigned to auxiliary war hospitals in Croatia (3-6). In contrast to this, the reports from the Afghanistan war (7) speak of high rates of various complications, even fatal outcomes, due to delays in delivering adequate surgical care. Therefore, the proverb "Time is money" could be paraphrased as "Time is life".

Following the mentioned principles, we treated a total of 597 patients at the Sturba war hospital and performed 1,014 minor surgical procedures (treatment of large nonpenetrating wounds with extensive soft tissue destruction, including injuries of muscles, tendons, small bones of the hand and foot) and 314 various major and complex surgical procedures (2). Wound debridement was performed in accordance with the NATO handbook instructions and findings of Fackler (8) and Ryan (9), based upon ballistic studies. When having doubts about sparing or radical excision, we chose a radical one.

We believe that this method of work decreased the $\frac{3}{\square}$ intraoperative and postoperative mortality rates to zero. Medicamentous therapy also played a significant role and응 cases of anaerobic or severe aerobic infections or sepsises? were not recorded (2).

The exception were casualties with isolated severe craniocerebral injuries. Following initial surgical carec and resuscitation they were immediately transferred to․ㅡㅁ. Split. This city in Croatia was the fourth echelon and our? rear, as well as the last resort for all the war casualtiese from the central and southwest parts of Bosnia and thees west part of Herzegovina.

Our work at the Sturba war hospital was put to an end16 months ago. Treatment, including secondary $\vec{\omega}$ reconstructive surgery and rehabilitation, were completed? in almost all of the patients. Due to the spread of war in Bosnia and Herzegovina, we were not able to summon allo patients for a detailed follow-up examination. Some of $\overrightarrow{+}$ them presented for the control check-up, and for rather ai large number of them we have data available from oure fellow-physicians who finished their treatment or were in the process of bringing it to an end. In these two groups ofo followed-up patients quite good end results wereobtained. Some of the patients were lost completely the follow-up. We learned that some went back to their? combat units and were injured or killed during the 1: year.

\section{Conclusions}

We were forced to adapt the NATO war doctrine echelonment in accordance with special circumstances Difs the war waged against Croatia, Bosnia and Herzegovina. The NATO organizational scheme was suitable for the treatment of war casualties in Bosnia and Herzegovina: and we strongly recommend it as a basic model which can be further developed in accordance with local conditions 3 and potentials in a defence war.

In addition to the recommended organization at theo level of the third echelon of medical care, specials attention should be paid to the second echelon $(1,2)$. It is an important link in the chain of evacuation and our opinion was that it should be staffed by young physicianstrained during graduate and postgraduate studies in theo treatment of medical-surgical emergencies. There are not enough surgeons and anaethesiologists in Bosnia and $\overline{3}$ Herzegovina that can be appointed to the third echelon, le alone the second. Therefore, it is not possible to form? mobile surgical teams, except in special cases such as aid given to the encircled hospitals in Sarajevo, Nova Bila,? Ž̀pče, etc (10).

The destiny of war casualties, except for those having fatal injuries, depends upon the quality and promptness of first aid and complete surgical treatment and resuscitationin If the first two echelons fulfill their tasks properly and thoo wounded are treated in terms of complete surgicaf 
treatment and resuscitation within the shortest possible period, preferably within one to two hours, they are given the best chance for quoad vitam et quoad sanationem.

\section{Acknowledgement}

We thank Drs. Matko Marušič and Ana Marušič for their help and friendly advice.

These are the views of the authors and cannot be attributed to the Government or the Ministry of Defence in any way.

\section{REFERENCES}

1. General considerations of forward surgery. In: Bowen T E, Bellammy R F, eds. Emergency war surgery. Second United States revision of the Emergency War Surgery NATO Handbook, United States Department of Defence. Washington, D.C.: United States Government Printing Office, 1988: 1-13.

2. Atias-Nikolov V, ŚSAić V, Kovać T, et al. Organization and work of the war hospital in Sturba near the town of Livno, Bosnia and Herzegovina. Milit Med 1994. (in press).

3. Stančić V, Gopč́ević A, Heitzler-Nikolić V, et al. War hospital in Velika Gorica: The first seventy days. Croatian Med J 1992; 33: (2 War Suppl): 184-92.
4. Petrač D, Georguević A, Kusić Z, et al. Organization and functioning of the Sisters of Mercy University Hospital in the war against Croatia. Croatian Med $J$ 1992; 33(2 War Suppl): 193-6.

5. Husar J, Eltz J. Mobile Surgical Teams in Croatian Special Forces Units (1990-1991). Croatian Med J 1993; 34: 276-9.

6. Perić M, Hamel D, Kelečcić M, et al. Battlefield experience of a Mobile Surgical Team: anaesthesiological approach. Croatian Med J 1992; 33(2 War Suppl): 175-83.

7. Bhatnagar M K, Smith G S, Trauma in the Aghan guerrilla war: Effects of lack of access to care. Surgery 1989; 105(6): 699-705.

8. FACKLER M L. Wound ballistics. A Review of common misconceptions. JAMA 1988; 259: 2730-6.

9. Ryan J M, CoOper G J, Haywood I R, et al. Field surgery on a future conventional battlefield: Strategy and wound management. Ann R Coll Surg Engl 1991; 73(1): 13-20.

10. Marušić A. Marušić M., Lang S. White road for Nova Bila and Silver Bosnia: A Chronology of the humanitarian convoy. Croatian Med J 1994; 35: 3-7. 